\title{
АДИКЦІї У ХВОРИХ НА ТРИВОЖНО-ФОБІЧНІ РОЗЛАДИ (ДІАГНОСТИКА ТА ЛІКУВАННЯ)
}

\begin{abstract}
Резюме. Якщо раніше в клінічній медичній практиці адиктивна поведінка розглядалась переважно в рамках субстанційних (хімічних) залежностей, то в сучасній психіатрії все більшої уваги набирає проблематика розвитку несубстанційних їх варіантів (психічних, поведінкових або, як ще їх позначають, психологічних залежностей: інтернет-залежність, компульсивне переїдання або навпаки надмірне захоплення дієтами чи здоровим способом життя, шопоголізм, трудоголізм, гемблінг, сексуальна залежність і багато інших).

Мета дослідження - провести клініко-психопатологічний аналіз адиктивної поведінки у хворих на тривожно-собічні розлади. Матеріали і методи. У статті використано клініко-психопатологічне дослідження (збір та аналіз анамнестичних даних, скарг та клінічного стану пацієнтів); система AUDIT-подібних тестів для комплексної оцінки адиктивного статусу, а також клінікостатистичні методи аналізу отриманих даних (методи описової та порівняльної статистики, кореляційний аналіз) із використанням комп'ютерних програм Excel та SPSS. У дослідженні взяли участь 49 осіб із тривожно-сробічними розладами (F 40,8) та 52 здорові особи (контрольна група).

Результати досліджень та їх обговорення. Аналіз адиктивного статусу досліджених осіб включав оцінку частот адиктивних феноменів різного ступеня вираження, адиктивного потенціалу об'єктів "вживання", середніх значень виразності адиктивних тенденцій за конкретними об'єктами "вживання”, загального показника адиктивності за сукупними даними системи AUDITподібних тестів, а також частот та характеру поєднання різних видів адикцій, аналіз кореляційних зв'язків між ними.

Висновки. Хворі на тривожно-фобічні розлади більш схильні до формування адикцій: стани залежності від різних об'єктів "вживання" фіксують у 57,1 \% хворих при р<0,0390. Найбільш розповсюдженими варіантами адикцій у всіх групах порівняння виступають залежність від тютюнокуріння, їжі, інтернету та роботи/навчання, що відображає загальнопопуляційні тенденції адиктивного стану нашого суспільства. Хворі на тривожно-фобічні розлади схильні до накопичення адикцій, тобто до формування “поєднаних" форм залежностей $\left(I_{c}=0,57\right)$ порівняно з практично здоровими особами $\left(I_{c}=0,25\right)$. До найбільш адиктивно небезпечних об'єктів, незалежно від групи порівняння, входили: тютюнокуріння, робота/навчання та їжа, які доповнювались іншими "специфрічно небезпечними" для окремих груп порівняння об'єктами "вживання".
\end{abstract}

Ключові слова: тривожно-фробічні розлади; адикції; коморбідність; клініко-психопатологічні особливості.

ВСтуп Феномен психіатричної коморбідності все частіше стає в центрі уваги фрахівців, які працюють у сорері психічного здоров'я [1, 2]. У практичній площині окремої уваги потребує визначення особливостей клінічного оформлення коморбідних розладів для підвищення якості їх діагностики та лікування [3, 4]. І якщо раніше в клінічній медичній практиці адиктивна поведінка розглядалась переважно в рамках субстанційних (хімічних) залежностей, то в сучасній психіатрії все більшої уваги набирає проблематика розвитку несубстанційних їх варіантів (психічних, поведінкових або, як ще їх позначають, психологічних залежностей: інтернет-залежність, компульсивне переїдання або навпаки надмірне захоплення дієтами чи здоровим способом життя, шопоголізм, трудоголізм, гемблінг, сексуальна залежність і багато інших) [5-8]. При цьому саме нехімічні варіанти залежностей вкрай рідко потрапляють в поле зору клініцистів, тому що "приховуються" за психопатологічною симптоматикою, яка завжди супроводжує адиктивну поведінку. Окрім того, часто адикції спостерігаються в рамках інших психічних і поведінкових розладів, і не класифікуються окремо. Зазначене визначає актуальність проблематики коморбідності хвороб залежності з іншими психічними розладами, особливостей та ознак поєднаних психопатологічних процесів, характеру взаємозв'язку однієї патології з іншою $[9,10]$.

Метою дослідження було провести клініко-психопатологічний аналіз адиктивної поведінки у хворих на тривожно-фробічні розлади.

МАТЕРІАЛИ І МЕТОДИ У статті використано клінікопсихопатологічне дослідження (збір та аналіз анамнестичних даних, скарг та клінічного стану пацієнтів); система AUDIT-подібних тестів для комплексної оцінки адиктивного статусу [10], а також клініко-статистичні методи аналізу отриманих даних (методи описової та порівняль- ної статистики, кореляційний аналіз) 3 використанням комп'ютерних програм Excel та SPSS.

У дослідженні взяли участь 49 осіб із тривожно-сробічними розладами (F 40,8) та 52 здорові особи (контрольна група).

РЕЗУЛЬТАТИ ДОСЛІДЖЕНЬ ТА ЇХ Й ОБГОВОРЕНня Аналіз адиктивного статусу досліджених осіб включав оцінку частот адиктивних феноменів різного ступеня вираження, адиктивного потенціалу об'єктів “вживання", середніх значень вираження адиктивних тенденцій за конкретними об'єктами “вживання", загального показника адиктивності за сукупними даними системи AUDITподібних тестів, а також частот та характеру поєднання різних видів адикцій, аналіз кореляційних зв'язків між ними.

Оцінку вираження адиктивних тенденцій у обстежених осіб проводили відповідно до запропонованих в AUDITтестах градацій (діапазонах вираження адиктивних тенденцій): 0 балів - відсутність досвіду "вживання"; 1-7 балів - відносно безпечне "вживання"; 8-15 балів - небезпечне "ризиковане" "вживання"; 16-19 балів - "вживання", що супроводжується шкідливими наслідками; 20-40 балів - наявність клінічної залежності.

Отримані результати дослідження щодо запропонованих градацій наведено в таблиці 1.

Згідно з отриманими даними, у хворих на тривожнофоббічні розлади достовірно частіше діагностували наявність залежностей (показники за даними AUDIT-тестів більше 20 балів) порівняно групою здорових. Так, у 57,1\% тривожно-сробічні розлади виявили клінічні ознаки залежності (у групі здорових - 40,38 \%, р<0,0458).

За показниками граничного рівня "вживання" (тобто зі шкідливими наслідками на рівні 16-19 балів) статистичних відмінностей між групами порівняння отримано не було. 
Таблиця 1. Результати діагностики станів адиктивної залежності за AUDIT-подібними тестами у здорових осіб та хворих на тривожно-фобічні розлади (за даними частотного аналізу)

\begin{tabular}{|c|c|c|c|}
\hline \multirow[b]{2}{*}{ Показник } & \multicolumn{2}{|c|}{ Частота ознак в групах порівняння* } & \multirow{2}{*}{$\begin{array}{c}\text { Достовірність відмінностей між } \\
\text { групами }(p)^{\star \star \star}\end{array}$} \\
\hline & $\begin{array}{l}\text { здорові } \\
(\mathrm{n}=52)\end{array}$ & $\begin{array}{l}\text { хворі }(F-40.8) * * \\
(n=49)\end{array}$ & \\
\hline Наявність залежності (більше 20 балів) & $21-40,38$ & $28-57,1$ & 0,0390 \\
\hline $\begin{array}{l}\text { Граничний рівень "вживання" (зі шкідливими } \\
\text { наслідками на рівні 16-19 балів) }\end{array}$ & $11-21,15$ & $7-14,3$ & 0,1390 \\
\hline Відсутність адиктивної поведінки (до 16 балів) & $20-38,46$ & $14-28,57$ & 0,0972 \\
\hline $\begin{array}{l}\text { Діагностовано “чисту” залежність } \\
\text { (один об'єкт залежності) }\end{array}$ & $15-28,85$ & $12-24,5$ & 0,1580 \\
\hline $\begin{array}{l}\text { Діагностовано “мультиморбідну” залежність } \\
\text { (більше ніж один об'єкт залежності) }\end{array}$ & $6-11,54$ & $16-32,65$ & 0,0073 \\
\hline
\end{tabular}

Примітки: 1) * - значення подано у форматі "Абс. кількість осіб /частота ознаки, частка (\%)";

2) ** - умовні скорочення - F 40.8 фобічні тривожні розлади;

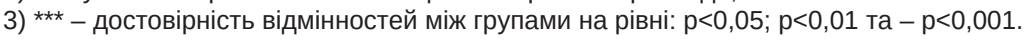

Аналіз результатів AUDIT-тестів також показав, що в деяких випадках у однієї особи діагностувалась наявність більш ніж однієї залежності, тобто "мультиморбідна" залежність, що достовірно частіше спостерігалось серед хворих на тривожно-сробічні (32,65 \%) розлади, порівняно зі здоровими особами (11,54 \%), при р<0,0073. Отримані дані свідчать про те, що хворі на тривожно-фообічні розлади схильні до накопичення різних станів залежності.

Феноменологічну структуру виявлених адикцій обстежених осіб представлено на рисунку 1 (представлено $\%$ осіб, у яких було діагностовано наявність клінічної залежності, тобто більше 20 балів за AUDIT-тестами).

Як видно з наведених даних, до "топ" трійки найбільш розповсюджених адикцій усіх обстежених осіб, незалежно від груп порівняння, увійшли наступні об'єкти “вживання": тютюнокуріння, їжа, інтернет.

Здорові особи найчастіше виявляли залежність від тютюну $(17,31 \%)$, потім від інтернету $(9,62 \%)$, роботи/ навчання $(7,69 \%)$, їжі $(7,69 \%)$, комп'ютерних ігор
(5,77\%), телебачення (5,77\%) та чаю або кави (3,35\%). Перелічені варіанти адикцій поєднують в собі як активуючу, так і седативну дії на емоційний стан.

У хворих же на тривожно-фобічні розлади стани залежності діагностувались не тільки частіше, ніж у здорових, але і в більш широкому діапазоні варіантів. Так, у структурі адикцій хворих на тривожно-сробічні розлади першість займає залежність від їжі (22,45 \%), що відображає тенденцію "заїдати" тривогу. Наступними є адикції, що також мають ефект "відволікання від тривожних почуттів" та їх седації: інтернет-залежність (20,41 \%), залежність від роботи/навчання (16,33 \%), залежність від снодійно-седативних речовин (14,29 \%) та тютюну $(14,29$ \%). Окрім того, в структурі адикцій хворих на тривожні розлади також представлено наявність залежностей від перегляду ТВ-програм (8,15 \%), чаю/кави (4,08 \%) та сексу $(2,04 \%)$.

Необхідно зазначити, що у хворих на тривожно-сробічні розлади адиктивні стани (тобто залежність) реєстру-
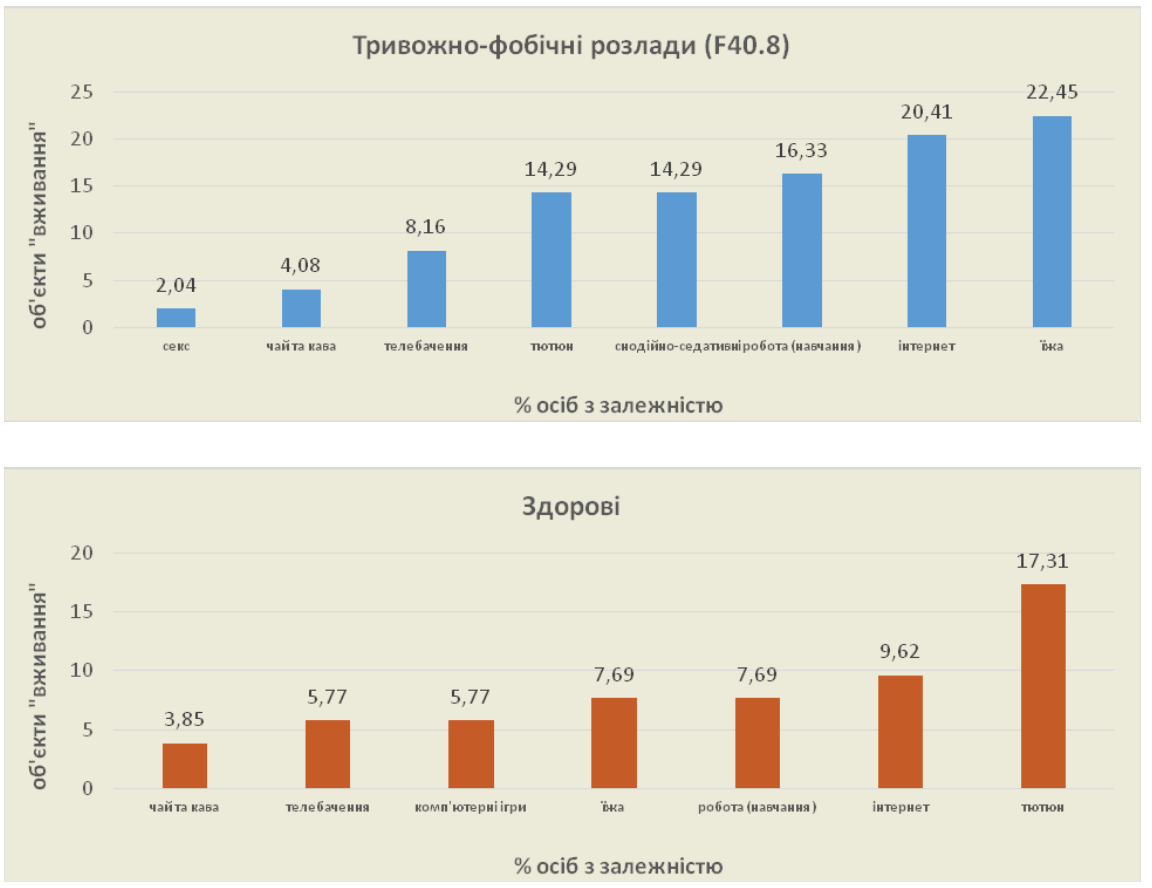

Рис. 1. Феноменологічна структура адикцій в обстежених групах осіб. 
ються частіше, ніж у здорових та представлені в більш широкому діапазоні об'єктів "вживання".

Окрім цього, хворі на тривожно-сробічні розлади також характеризуються високою вірогідністю поєднання декількох станів залежності (табл. 1).

Згідно з отриманими даними, встановлено, що серед хворих на тривожно-сробічні розлади достовірно частіше зустрічались "поєднані" варіанти залежностей (у 32,65 та 38,18 \% випадків), порівняно зі здоровими (11,54 \% випадків) при p<0,0073; p<0,0011 відповідно. Слід зазначити, що найчастіше у хворих на тривожно-сробічні розлади спостерігалось поєднання станів залежності від їжі та інтернету (12,24 \% випадків), порівняно зі здоровими, у яких подібне поєднання зустрічалось лише в 1,9% випадків, при $p<0,0422$.

У цілому отримані дані свідчать, що хворі на тривожно-фробічні розлади є більш схильними до формування адиктивних станів та частіше характеризуються наявністю сполучених варіантів адикцій. Саме для детального аналізу характеру поєднання декількох адикцій одночасно був розрахований спеціальний показник - індекс сполучення об'єктів “вживання", що виражає здатність однієї залежності "притягувати" до себе інші.

Індекс сполучення об'єктів "вживання" розраховували за наступною формулою: $I_{c}=N_{\text {comb }} / N_{\text {given }}$, де $\mathrm{N}_{\text {given }}-$ кількість осіб в групі з залежністю від окремо заданого об'єкту "вживання"; $\mathrm{N}_{\text {соть }}$ - сумарна кількість випадків наявності випадків сполучення залежності від заданого об'єкту "вживання" з залежностями від інших об'єктів "вживання" серед осіб групи обстеження.

Індекс сполучення розраховували окремо за конкретними об'єктами "вживання" (рис. 2), а також обчислювали узагальнений показник "сполучення" адикцій як середній бал за всіма об'єктами "вживання", що аналізувалися для кожної групи обстеження (рис. 3).

На рисунку 2 представлено рейтинги індексів сполучення окремо за конкретними об'єктами “вживання" для кожної з груп обстежених.

Наведені показники свідчать про середню кількість адикцій, окрім тієї що аналізується, у респондентів конкретної групи. Так, у практично здорових осіб зафіксовано найнижчі показники індексів сполучення залежностей, 3 яких найвищим є індекс сполучення за об'єктом "вживання" комп'ютерні ігри $\left(I_{c}=1,0\right)$. Інші об'єкти “вживання" у практично здорових осіб за індексом сполучення не перетинають поріг в 1,0 бал і дорівнюють: інтернет $\left(I_{c}=0,8\right) ;$ їжа $\left(I_{c}=0,75\right) ;$ телебачення $\left(I_{c}=0,67\right) ;$ чай $/$ кава $\left(I_{c}=0,5\right) ;$ робота/навчання $\left(I_{c}=0,5\right)$ та тютюнокуріння $\left(I_{c}=0,33\right)$.

У хворих на тривожно-сробічні розлади 7 об'єктів "вживання" характеризуються сполученням з ще однією і більше залежностей $\left(I_{c} \geq 1\right)$. За рейтингом індексів сполучення адикцій у хворих на тривожно-фробічні розлади переважає секс $\left(I_{c}=2,0\right)$, тобто хворі з тривожно-сробічними розладами, які залежні від сексу, мають в середньому ще 2 залежності від інших об'єктів. Далі за рейтингом "сполучення" у хворих цієї групи ідуть чай/кава $\left(I_{c}=1,5\right)$, снодійно-седативні препарати $\left(I_{c}=1,29\right)$, їжа $\left(I_{c}=1,27\right)$, телебачення $\left(I_{c}=1,25\right)$, інтернет $\left(I_{c}=1,0\right)$, робота $\left(I_{c}=1,0\right)$ та тютюнокуріння $\left(I_{c}=0,86\right)$.

Згідно з отриманими даними, показник сполучення адикцій у хворих на тривожно-фробічні розлади становив $\left(I_{c}=0,57\right)$, разом з тим, час серед практично здорових осіб показник сполучення адикцій був найменшим $\left(I_{c}=0,25\right)$ (рис. 3).

У цілому за результатами аналізу показників індексу сполучення варто ще раз підкреслити, що хворі на тривожно-фообічні розлади не тільки більш схильні до формування станів залежності, а й ще також більш схильні до накопичення декількох адикцій одночасно.

Продовжуючи аналізувати особливості адиктивного статусу обстежених осіб, було проведено порівняльний аналіз частот вираження адиктивних френоменів за окремими AUDIT-тестами (табл. 2).
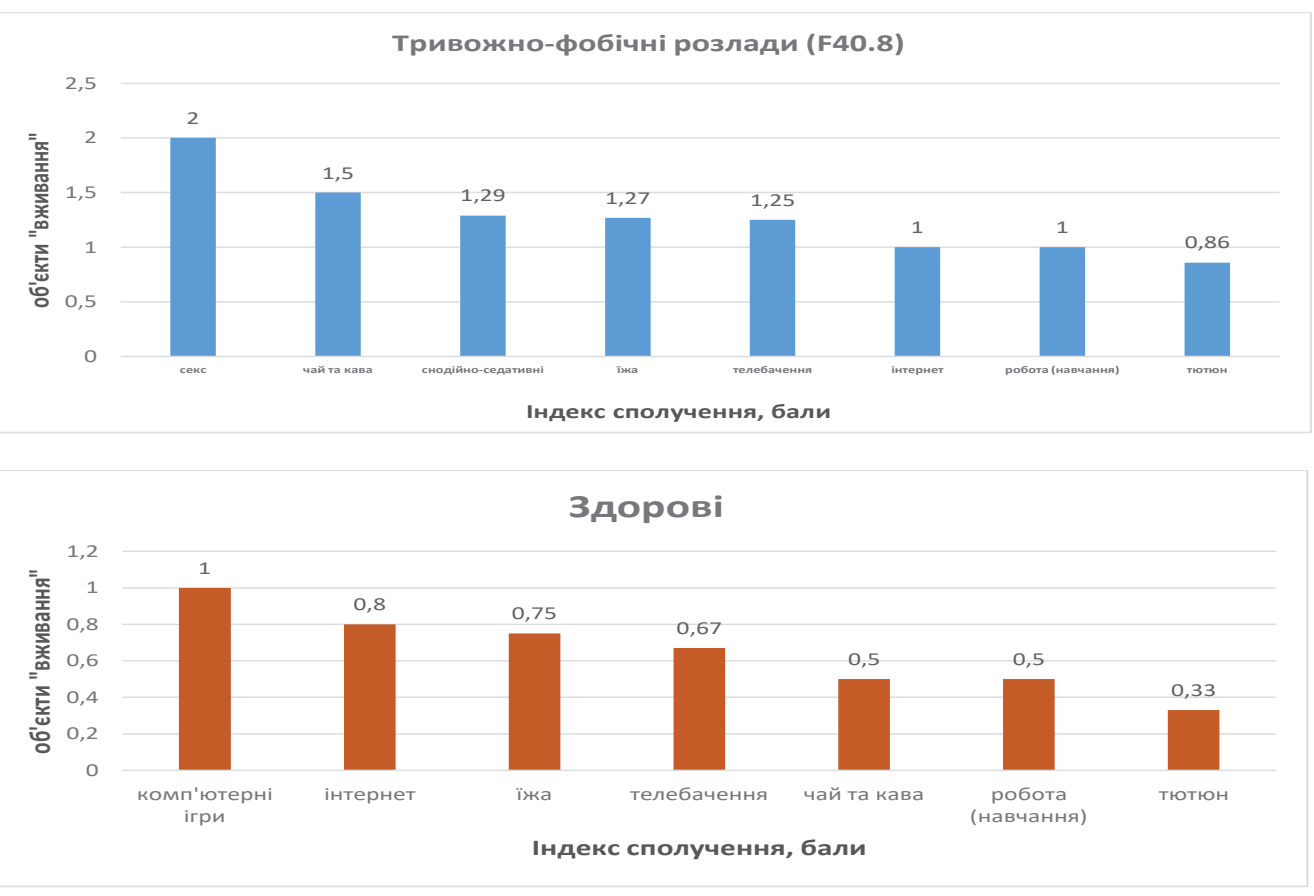

Рис. 2. Індекси сполучення різних об'єктів "вживання" в обстежених осіб. 


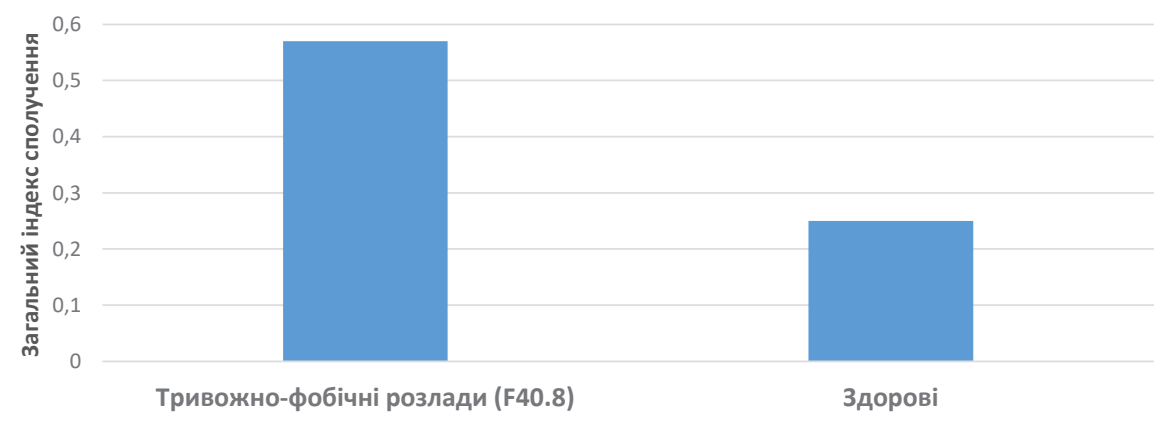

Рис. 3. Загальний показник (середній бал) індексу сполучення адикцій у обстежених осіб.

Таблиця 2. Вираження адиктивних феноменів за окремими AUDIT-тестами у здорових осіб та хворих на тривожнофобічні розлади

\begin{tabular}{|c|c|c|c|c|}
\hline \multirow{2}{*}{\multicolumn{2}{|c|}{ Показник }} & \multicolumn{2}{|c|}{ Частота ознак у групах порівняння夫 } & \multirow{2}{*}{$\begin{array}{c}\text { Достовірність відмінностей } \\
\text { між групами (p)*** } \\
\text { здорові (F 40.8) }\end{array}$} \\
\hline & & здорові (n=52) & хворі $(F \text { 40.8) })^{\star \star}(n=49)$ & \\
\hline \multirow[t]{6}{*}{ ІІжа (FOOD-UDIT) } & 0 балів & - & 8,16 & 0,0518 \\
\hline & 1-7 балів & 38,46 & 24,49 & 0,0555 \\
\hline & 8-15 балів & 44,23 & 34,69 & 0,1007 \\
\hline & 16-19 балів & 9,62 & 10,20 & 0,2579 \\
\hline & $>1<19$ балів & 92,31 & 69,38 & 0,0026 \\
\hline & $>19$ балів & 7,69 & 22,45 & 0,0265 \\
\hline \multirow[t]{6}{*}{ Секс (SEX-UDIT) } & 0 балів & 21,15 & 10,20 & 0,0720 \\
\hline & 1-7 балів & 57,69 & 67,35 & 0,0996 \\
\hline & 8-15 балів & 17,31 & 12,24 & 0,1729 \\
\hline & 16-19 балів & 3,85 & 8,16 & 0,2216 \\
\hline & $>1<19$ балів & 78,85 & 87,75 & 0,1056 \\
\hline & >19 балів & - & 2,04 & 0,4851 \\
\hline \multirow{6}{*}{$\begin{array}{l}\text { Робота (навчання) (WORK(EDU)- } \\
\text { UDIT) }\end{array}$} & 0 балів & 5,77 & 14,29 & 0,0988 \\
\hline & 1-7 балів & 48,08 & 30,61 & 0,0330 \\
\hline & 8-15 балів & 23,08 & 20,41 & 0,1809 \\
\hline & 16-19 балів & 15,38 & 18,37 & 0,1933 \\
\hline & $>1<19$ балів & 86,54 & 69,39 & 0,0224 \\
\hline & > 19 балів & 7,69 & 16,33 & 0,1024 \\
\hline \multirow[t]{6}{*}{ Телебачення (TV-UDIT) } & 0 балів & 7,69 & 12,24 & 0,1970 \\
\hline & 1-7 балів & 53,85 & 32,65 & 0,0163 \\
\hline & 8-15 балів & 28,85 & 40,82 & 0,0756 \\
\hline & 16-19 балів & 3,85 & 6,12 & 0,3084 \\
\hline & $>1<19$ балів & 86,55 & 79,59 & 0,1374 \\
\hline & >19 балів & 5,77 & 8,16 & 0,2722 \\
\hline \multirow[t]{6}{*}{ Інтернет (INTERNET-UDIT) } & 0 балів & 7,69 & 14,29 & 0,1463 \\
\hline & 1-7 балів & 40,38 & 32,65 & 0,1190 \\
\hline & 8-15 балів & 36,54 & 26,53 & 0,0957 \\
\hline & 16-19 балів & 5,77 & 6,12 & 0,3212 \\
\hline & $>1<19$ балів & 76,92 & 65,3 & 0,0253 \\
\hline & >19 балів & 9,62 & 20,41 & 0,0717 \\
\hline \multirow[t]{6}{*}{ Азартні ігри (GAMBLING-UDIT) } & 0 балів & 86,54 & 100 & 0,0077 \\
\hline & 1-7 балів & 9,6 & - & 0,0328 \\
\hline & 8-15 балів & 3,85 & - & 0,2625 \\
\hline & 16-19 балів & - & - & - \\
\hline & $>1<19$ балів & 13,45 & - & 0,0078 \\
\hline & >19 балів & - & - & - \\
\hline
\end{tabular}


Продовження табл. 2

\begin{tabular}{|c|c|c|c|c|}
\hline \multicolumn{2}{|l|}{ Показник } & \multicolumn{2}{|c|}{ Частота ознак у групах порівняння* } & \multirow{3}{*}{$\begin{array}{c}\text { Достовірність відмінностей } \\
\text { між групами (p)**夫 } \\
\text { здорові (F 40.8) } \\
0,1582 \\
\end{array}$} \\
\hline & & \multirow{2}{*}{$\begin{array}{c}\text { здорові }(\mathrm{n}=52) \\
55,77\end{array}$} & \multirow{2}{*}{$\frac{\text { хворі }(F-40.8)^{\star \star}(n=49)}{55,10}$} & \\
\hline \multirow[t]{6}{*}{ Комп'ютерні ігри (COMP-UDIT) } & 0 балів & & & \\
\hline & 1-7 балів & 28,85 & 34,70 & 0,1391 \\
\hline & 8-15 балів & 9,62 & 10,20 & 0,2579 \\
\hline & 16-19 балів & - & - & - \\
\hline & $>1<19$ балів & 38,47 & 44,9 & 0,1294 \\
\hline & $>19$ балів & 5,77 & - & 0,1326 \\
\hline \multirow[t]{6}{*}{ Шопінг (SHOPPING-UDIT) } & 0 балів & - & 10,20 & 0,0240 \\
\hline & 1-7 балів & 78,85 & 55,10 & 0,0068 \\
\hline & 8-15 балів & 21,15 & 32,65 & 0,0772 \\
\hline & 16-19 балів & - & 2,04 & 0,4851 \\
\hline & $>1<19$ балів & 100 & 89,79 & 0,0241 \\
\hline & >19 балів & - & - & - \\
\hline \multirow[t]{6}{*}{ Читання (READING-UDIT) } & 0 балів & 1,92 & 22,45 & 0,0012 \\
\hline & 1-7 балів & 73,08 & 61,22 & 0,0761 \\
\hline & 8-15 балів & 21,15 & 14,29 & 0,1087 \\
\hline & 16-19 балів & 3,85 & 2,04 & 0,3898 \\
\hline & $>1<19$ балів & 98,08 & 77,55 & 0,0013 \\
\hline & $>19$ балів & - & - & - \\
\hline \multirow[t]{6}{*}{ Алкоголь (AUDIT) } & 0 балів & 9,62 & 26,53 & 0,0182 \\
\hline & 1-7 балів & 73,08 & 55,10 & 0,0286 \\
\hline & 8-15 балів & 17,31 & 8,16 & 0,0955 \\
\hline & 16-19 балів & - & 8,16 & 0,0518 \\
\hline & $>1<19$ балів & 90,39 & 71,42 & 0,0108 \\
\hline & $>19$ балів & - & - & - \\
\hline \multirow[t]{6}{*}{ Тютюнокуріння (TOBACCO-UDIT) } & 0 балів & 59,62 & 57,14 & 0,1549 \\
\hline & 1-7 балів & 9,62 & 14,29 & 0,1872 \\
\hline & 8-15 балів & 3,85 & 2,04 & 0,3898 \\
\hline & 16-19 балів & 9,62 & 12,24 & 0,2286 \\
\hline & $>1<19$ балів & 23,09 & 28,57 & 0,1479 \\
\hline & $>19$ балів & 17,31 & 14,29 & 0,1976 \\
\hline \multirow[t]{6}{*}{ Чай та кава (COFFEE(TEA)-UDIT) } & 0 балів & - & 12,24 & 0,0110 \\
\hline & 1-7 балів & 19,23 & 24,49 & 0,1557 \\
\hline & 8-15 балів & 69,23 & 57,14 & 0,0749 \\
\hline & 16-19 балів & 7,69 & 2,04 & 0,1674 \\
\hline & $>1<19$ балів & 96,15 & 83,67 & 0,0311 \\
\hline & >19 балів & 3,85 & 4,08 & 0,3819 \\
\hline \multirow[t]{6}{*}{ Канабіноїди (CANNABIS-UDIT) } & 0 балів & 100,00 & 100,00 & - \\
\hline & 1-7 балів & - & - & - \\
\hline & 8-15 балів & - & - & - \\
\hline & 16-19 балів & - & - & - \\
\hline & $>1<19$ балів & - & - & - \\
\hline & >19 балів & - & - & - \\
\hline \multirow[t]{6}{*}{ лОС (SOLVENTS-UDIT) } & 0 балів & 96,15 & 100,00 & 0,2625 \\
\hline & 1-7 балів & 3,85 & - & 0,2625 \\
\hline & 8-15 балів & - & - & - \\
\hline & 16-19 балів & - & - & - \\
\hline & $>1<19$ балів & 3,85 & - & 0,2626 \\
\hline & >19 балів & - & - & - \\
\hline \multirow[t]{3}{*}{ Снодійно-седативні (SEDATIVE-UDIT) } & 0 балів & 100,00 & 51,02 & 0,0000 \\
\hline & 1-7 балів & - & 12,24 & 0,0110 \\
\hline & 8-15 балів & - & 14,29 & 0,0049 \\
\hline
\end{tabular}


Продовження табл. 2

\begin{tabular}{|c|c|c|c|c|}
\hline \multirow{2}{*}{\multicolumn{2}{|c|}{ Показник }} & \multicolumn{2}{|c|}{ Частота ознак у групах порівняння* } & \multirow{3}{*}{$\begin{array}{c}\begin{array}{c}\text { Достовірність відмінностей } \\
\text { між групами (p) }\end{array} \\
\text { здорові (F 40.8) } \\
0,0519\end{array}$} \\
\hline & & \multirow{2}{*}{$\frac{\text { здорові }(\mathrm{n}=52)}{-}$} & \multirow{2}{*}{$\frac{\text { хворі }(\mathrm{F} \mathrm{40.8)* \star}(\mathrm{n}=49)}{8,16}$} & \\
\hline & 16-19 балів & & & \\
\hline & $>1<19$ балів & - & 34,69 & 0,000001 \\
\hline & >19 балів & - & 14,29 & 0,0049 \\
\hline \multirow{6}{*}{$\begin{array}{l}\text { Психостимулятори (STIMULANT- } \\
\text { UDIT) }\end{array}$} & 0 балів & 100,00 & 89,80 & 0,0241 \\
\hline & 1-7 балів & - & 2,04 & 0,4851 \\
\hline & 8-15 балів & - & 6,12 & 0,1105 \\
\hline & 16-19 балів & - & 2,04 & 0,4851 \\
\hline & $>1<19$ балів & - & 10,2 & 0,0241 \\
\hline & >19 балів & - & - & - \\
\hline \multirow[t]{6}{*}{ Опіоїди (OPIATE-UDIT-UDIT) } & 0 балів & 100,00 & 91,84 & 0,0518 \\
\hline & 1-7 балів & - & 6,12 & 0,1105 \\
\hline & 8-15 балів & - & 2,04 & 0,4851 \\
\hline & 16-19 балів & - & - & - \\
\hline & $>1<19$ балів & - & 8,16 & 0,0519 \\
\hline & > 19 балів & - & - & - \\
\hline \multirow{6}{*}{$\begin{array}{l}\text { Галюциногени (PSYCHODELICS- } \\
\text { UDIT) }\end{array}$} & 0 балів & 100,00 & 100,00 & - \\
\hline & 1-7 балів & - & - & - \\
\hline & 8-15 балів & - & - & - \\
\hline & 16-19 балів & - & - & - \\
\hline & $>1<19$ балів & - & - & - \\
\hline & >19 балів & - & - & - \\
\hline
\end{tabular}

Примітки: 1) * - значення подано у фрорматі “частота ознаки, частка (\%)";

2) ** - умовні скорочення - F 40.8 - інші фробічні тривожні розлади;

3) *** - достовірність відмінностей між групами на рівні: $p<0,05 ; p<0,01$ та - p<0,001 виділено заливкою сірого кольору різної інтенсивності.

Показники частот досвіду "вживання" без ознак залежності (особи, які набрали за результатами AUDIT-тестів від 1 до 19 балів (>1<19 балів)). Згідно з отриманими даними, серед практично здорових осіб значно частіше виявлялась наявність безпечного досвіду "вживання" більшості потенційно адиктивних об'єктів, таких, як їжа, секс, робота/навчання, інтернет, азартні ігри, шопінг, читання, алкоголь та чай/кава, за винятком снодійно-седативних речовин та психостимуляторів, досвід “вживання", яких у здорових осіб взагалі не було зафіксовано.

Серед хворих на тривожно-фробічні розлади, порівняно зі здоровими, достовірно частіше діагностувалась залежність (більше 19 балів) від їжі (20,41 та 9,62 \% відповідно, при $\mathrm{p}<0,0265)$ та снодійно-седативних речовин $(14,29$ та 0 \% відповідно, при р<0,0049).

При цьому серед здорових осіб значно частіше відмічалось "безпечне" (на рівні 1-7 балів) "вживання" таких об'єктів, як секс (57,69 \%), робота/навчання $(48,08 \%$, порівняно 3 хворими на тривожно-сробічні розлади - 30,61 \%, при р<0,033), телебачення (53,85 \%, порівняно з хворими на тривожно-сробічні - 32,65 \%, при p<0,0163), азартні ігри $(9,6 \%$, порівняно з хворими на тривожно-сробічні розлади - $0 \%$, при р<0,0328, які взагалі ніколи "не вживали" ці об'єкти), шопінг (78,85\%, порівняно з хворими на тривожносробічні - 55,1 \%, при р<0,0068), читання $(73,08 \%$, при $\mathrm{p}<0,0321)$, алкоголь $(73,08 \%$, порівняно 3 хворими на тривожно-фробічні розлади - 55,1\%, при р<0,0286).

Отримані дані свідчать про більшу стійкість здорових осіб до фрормування залежності від вищеперелічених об'єктів "вживання", незважаючи на досвід "вживання". А також про своєрідну “антистресову” дію (як засіб зняття емоційної напруги) перелічених об'єктів у варіанті їх помірного використання.

Відсутність досвіду "вживання" більшості хімічних речовин (за винятком ЛОС) відмічали 100 \% здорових осіб. При цьому хворі на тривожно-фообічні розлади значно частіше (на рівні $p<0,00001)$ вказували на наявність досвіду "вживання" снодійно-седативних речовин, більш того використовували їх на ризикованому рівні (4,29 \%).

Хворі на тривожно-фробічні розлади вказували на наявність досвіду "вживання" на різному рівні психостимуляторів (у 11,2 \% випадків) та опіоїдів (у 8,16 \% випадків), при його 100 \% відсутності у здорових обстежених. Це, у свою чергу, підтверджує той фракт, що ці речовини сприяють виникненню (провокують розвиток) тривожно-сробічної симптоматики.

Розроблений комплекс терапії, що включав техніки екзистенціальної психотерапії та проблемно-орієнтованої терапії, яку застосовували у поєднанні з фрармакотерапією (хлортротиксен, карбамазепін), використовували 24 дні у стаціонарних умовах, 2 місяці - амбулаторно. Основними критеріями ефективності терапевтичного комплексу були редукція тривожно-фробічної симптоматики та ознак "вживання" (після лікування клінічні ознаки залежностей реєструвалися у 10,2 \% пацієнтів, р<0,001).

ВИСНОВКИ 1. Хворі на тривожно-сробічні розлади більш схильні до фрормування адикцій: стани залежності від різних об'єктів “вживання" фріксуються у 57,1% хворих, при р<0,0390. 
2. Найбільш розповсюдженими варіантами адикцій у всіх групах порівняння виступають залежність від тютюнокуріння, їжі, інтернету та роботи/навчання, що відображає загальнопопуляційні тенденції адиктивного стану нашого суспільства.

3. Встановлено, що хворі на тривожно-сробічні розлади схильні до накопичення адикцій, тобто до формування “поєднаних" фрорм залежностей $\left(I_{c}=0,57\right)$ порівняно
3 практично здоровими особами $\left(I_{c}=0,25\right)$. До найбільш адиктивно небезпечних об'єктів, незалежно від групи порівняння, входили: тютюнокуріння, робота/навчання та їжа, які доповнювались іншими "специфічно небезпечними" для окремих груп порівняння об'єктами "вживання".

4. Ефективним комплексним терапевтичним засобом виявився комплекс психотерапії та фрармакотерапії.

\section{СПИСОК ЛІТЕРАТУРИ}

1. Автономов Д. А. Проблема тревоги, аддикции и "новых" симптомов у современных пациентов с позиции психоанализа / Д. А. Автономов // Наркология. - № 8. - 2011. - С. 82-87.

2. Гуревич Г. Л. Коморбидные расстройства в наркологической практике / Г. Л. Гуревич. - М. : ИД Медпрактика-М, 2007. - С. 120.

3. Зальмунин К. Ю. Химические и нехимические аддикции в аспекте сравнительной аддиктологии / К. Ю. Зальмунин, В. Д. Менделевич // Журнал неврологии и психиатрии им. С. С. Корсакова. - Спецвыпуск. - 2014. - 114 (5). - С. 3-8.

4. Зільберблат Г. М. Ресрормування психіатричної служби крізь призму наркологічних проблем / Г.М.Зільберблат // Український вісник психоневрології. - 2015. - Т. 23, вип. 3 (84). - С. 74-78.

5. Система AUDIT-подобных тестов для комплексной оценки аддиктивного статуса индивида и популяции / И. В. Линский, А. И. Минко, А. Ф. Артемчук [и др.] // Новости украинской психиатрии. - Киев ; Харьков, 2009. - Режим доступа: http://www. psychiatry.ua/ articles/paper313.htm.

6. Comorbidity of Mental and Physical Disorders / N. Sartorius, R. I. G. Holt, Maj M. / Key Issues in Mental Health. - 2015. - Vol. 179. $-188 \mathrm{p}$.
7. Van Praag H. M. Comorbidity in psychiatry / H. M. Van Praag // Br. J. Psychiatry. - 1996. - Vol. 168, Suppl. 30. - P. 129-134.

8. Колядко С. П. Эмоциональная абстиненция как биопсихологический феномен в переходных процессах при неравновесном гомеостазе эмоционального фонда / С. П. Колядко, Т. М. Воробьева // Психическое здоровье. - 2014. - № 1. C. $12-15$.

9. Семке В. Я. Исследовательские подходы к классификации пограничных и аддиктивных расстройств / В. Я. Семке // Медицинская психология в России : электрон. науч. журн. - 2012. № 2. URL: http:// medpsy.ru

10. Система AUDIT-подобных тестов для комплексной оценки аддиктивного статуса индивида и популяции [Электронный ресурс] / Линский И. В., Минко А. И., Артемчук А. Ф., Гриневич Е. Г., Маркова М. В., Мусиенко Г. А., Шалашов В. В., Маркозова Л. М., Самойлова Е. С., Пономарёв В. И., Бараненко А. В., Минко А. А., Гольцова С. В., Сергиенко О. В., Линская Е. И. // Новости украинской психиатрии. - Киев ; Харьков, 2009. - Режим доступа: http://www.psychiatry.ua/ articles/paper313.htm.

Отримано 26.07.17

CM. M. Denysenko

Institute of Neurology, Psychiatry and Narcology, Kharkiv

\section{ADDICTION IN PATIENTS WITH ANXIETY-PHOBIC DISORDERS (DIAGNOSIS AND TREATMENT)}

Summary. If in the clinical psychiatric practice the addictive behavior was considered mainly within the framework of the substantive (chemical) dependencies, in modern psychiatry the problems of the development of non-substitutional variants (psychological, behavioral or, as they are denoted, psychological dependencies: Internet addiction, compulsive overeating or vice versa, excessive passion for diet or a healthy lifestyle, shopoholism, workholism, gembling, sexual intercourse, and many others).

The aim of the study - to conduct a clinical and psychopathological analysis of addictive behavior in patients with anxiety-phobic disorders.

Materials and Methods: Clinical and psychopathological research (collection and analysis of anamnestic data, complaints and clinical condition of patients); the system of AUDIT-like tests for the comprehensive assessment of addictive status, as well as clinical and statistical methods for analyzing the data obtained (descriptive and comparative statistics, correlation analysis) using Excel and SPSS computer programs. The study involved 49 people with anxiety-phobic disorders ( $F$ 40.8) and 52 healthy subjects (control group).

Results and Discussion. The analysis of the addictive status of the subjects involved included the estimation of the frequencies of addictive phenomena of varying degrees of severity, the additive potential of the objects of use, the mean values of the expressiveness of the addictive tendencies for the specific objects of use, the total index of addiction according to the aggregate data of the system of AUDIT-like tests, as well as the frequency and nature a combination of different types of addictions, analysis of the correlation between them.

Conclusions. Patients with anxiety-phobic disorders are more prone to the formation of addictions: states of dependence on various objects of use are recorded in $57.1 \%$ of patients, with $p<0.0390$. The most common variants of addiction in all groups of comparison depend on tobacco, food, internet and work / education, which reflect the general population trends of the addictive state of our society. Patients with anxiety and phobic disorders are prone to accumulation of addictions, that is to form the "combined" forms of dependencies (Is = 0.57), compared with practically healthy individuals (Is $=0.25$ ). The most addictively dangerous objects, regardless of the comparison group, were tobacco, work / training and food, which were supplemented by other "specifically dangerous" for certain groups of comparison of objects of use.

Key words: anxiety-phobic disorders; addiction; comorbidity; clinical and psychopathological features. 
ISSN 1681-276Х. ВІСНИК НАУКОВИХ ДОСЛІДЖЕНЬ. 2017. № 3

ОМ. М. Денисенко

ГУ “Институт неврологии, психиатрии и наркологии НАМН Украины”, г. Харьков АДДИКЦИИ У БОЛЬНЫХ ТРЕВОЖНО-ФОБИЧЕСКИМИ РАССТРОЙСТВАМИ (ДИАГНОСТИКА И ЛЕЧЕНИЕ)

Резюме. Если раньше в клинической медицинской практике аддиктивное поведение рассматривалось преимущественно в рамках субстанциональных (химических) зависимостей, то в современной психиатрии все большее внимание набирает проблематика развития несубстанционных их вариантов (психических, поведенческих или, как еще их обозначают, психологических зависимостей: интернет-зависимость, компульсивное переедание или наоборот чрезмерное увлечение диетами или здоровым образом жизни, шопоголизм, трудоголизм, гемблинг, сексуальная зависимость и многие другие).

Цель исследования - провести клинико-психопатологический анализ аддиктивного поведения у больных тревожно-оробическими расстройствами.

Материалы и методы. В статье использованы клинико-психопатологическое исследование (сбор и анализ анамнестических данных, жалоб и клинического состояния пациентов); система AUDIT-подобных тестов для комплексной оценки аддиктивного статуса, а также клинико-статистические методы анализа полученных данных (методы описательной и сравнительной статистики, корреляционный анализ) с использованием компьютерных программ Excel и SPSS. B исследовании приняли участие 49 человек с тревожно-фробическими расстройствами (F 40,8) и 52 здоровых лиц (контрольная группа).

Результаты исследований и их обсуждение. Анализ аддиктивного статуса исследованных лиц включал оценку частот аддиктивных френоменов различной степени выраженности, аддиктивного потенциала объектов применения, средних значений выраженности аддиктивных тенденций по конкретным объектам применения, общего показателя адиктивности по совокупным данным системы AUDIT-подобных тестов, а также частот и характера сочетание различных видов аддикций, анализ корреляционных связей между ними.

Выводы. Больные тревожно-фобическими расстройствами более склонны к формированию аддикций: состояния зависимости от различных объектов употребление фриксируются в 57,1 \% больных при р<0,0390. Наиболее распространенными вариантами аддикций во всех группах сравнения выступают зависимость от табака, пищи, интернета и работы/учебы, отражающих общие популяционные тенденции аддиктивного состояния нашего общества. Больные тревожно-фобическими расстройствами склонны к накоплению аддикций, то есть к фрормированию "объединенных" фрорм зависимостей (I =0,57) по сравнению с практически здоровыми лицами $\left(I_{c}=0,25\right)$. K наиболее аддиктивно опасным объектам, независимо от группы сравнения, входили: табак, работа/учеба и пища, которые дополнялись другими “специфически опасными" для отдельных групп сравнения объектами применения.

Ключевые слова: тревожно-фробические расстройства; аддикции; коморбидность; клинико-психопатологические особенности. 